\title{
Spending Surges: Considerations Toward a Proposed Model for Explaining Budgetary Slack in Expiring Budgets
}

\author{
Shawn L. Robey \\ Department of Accounting \& Finance, University of Southern Indiana \\ 8600 University Boulevard, Evansville, IN 47712, USA \\ Mark A. McKnight (Corresponding author) \\ Department of Accounting \& Finance, University of Southern Indiana \\ 8600 University Boulevard, Evansville, IN 47712, USA \\ Tel: 1-812-465-1012Ｅ-mail: mamcknight@usi.edu
}

Received: May 10, 2018

doi:10.5296/ijafr.v8i2.13121
Accepted: May 25, 2018

Published: June 6, 2018

URL: https://doi.org/10.5296/ijafr.v8i2.13121

\begin{abstract}
A review of an expiring budget and its impact on the budgeting process is very important. Two issues can quickly arise from the practice of budgeting based on budgetary slack. First, a department might feel incentivized to initially reduce (or hold back) spending during the early stages of the budgeting cycle. Second, as an extension to the prior idea, the department might experience an increase in spending as the end of the budget cycle draws near. The present research serves two purposes: The first purpose of this paper is to explore spending surges towards the end of a budgeting cycle. The secondary purpose of the paper is to explore the honesty of a department by using slack levels as an indicator. Based on the review of the literature, two general research questions will guide the development of a theoretical model to explain spending surges toward the end of a budgetary cycle.
\end{abstract}

Keywords: Budgeting, Budgetary slack, Spending, Honesty 


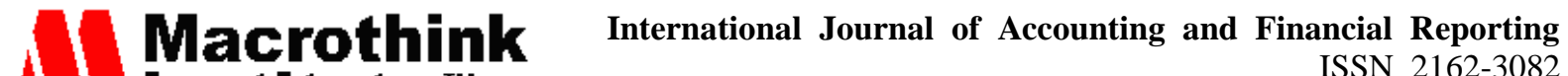 Institute"'

\section{Introduction}

A well designed budget will be flexible and able to respond to changes (Goldstein, 2005). With this in mind, the problem to be addressed is to what extent expiring budgets undermine the budgeting process of a particular unit or organization. Gallani et al., (2018) notes that a disadvantage of employee participation in budgeting provides employees an opportunity to misreport private information, which is often caused by economic motives such as slack acquisition (Baiman \& Lewis, 1989). More specifically, budgetary slack has been defined as the express incorporation of budget amounts that make it easier to attain (Dunk, 1993). Managers may create slack in budgets that impact both revenues and costs (Schiff \& Lewin, 1970).

Two issues can quickly arise from the practice of budgeting using budgetary slack. First, departments or units could be incentivized to intentionally reduce spending during the early stages of the budgeting cycle. This creates the secondary issue, which is the accumulation of unused resources to cope with the uncertainty of future expenses facing the department or unit. Essentially, the manager creates a perceived "rainy day" fund for use within a department or unit, which could predicate an increase in departmental spending as the end of the budget cycle draws near. This issue arises from there being no incentive, in the department's eyes, to save resources (Liebman \& Mahoney, 2013). Amounts not spent may be reallocated or, in some cases, reverted back to organization (Goldstein, 2005). Any unspent resources may indicate a lack of need, leading to decreased funding in the future (Jones, 2005). The excess in resource allocation to a department can be viewed as slack in the budget, because the additional resources used are at the benefit of the department and not in the best interests of the organization (Church, Hannan, \& Kuang, 2012).

A number of studies have examined the implications of slack on a budget and the factors leading to its creation (Church et al., 2012; Hobson, Mellon, \& Stevens, 2011; Hartmann \& Maas, 2010; Liessem, Schedlinsky, Schwering, \& Sommer, 2015). Slack negatively impacts a budget by taking resources away from future opportunities that could have awarded the department, unit or organization with a better return on investment.

Abdullah and Brink (2017) conclude that managers often have incentives to misreport their private information and inaccurately set budget targets in order to create budgetary slack. However, the authors point out "this study is subject to the limitations derived from the consequences of experimental research...this setting might not be generally applicable in real practice" (p. 21).

Budgetary slack is often the result of questionable ethical practices or ineffective management strategies related to budgeting. Unintended consequences of poor budget management and the development and existence of budgetary slack can have significant negative impacts on an organization and its financial position, as well as the unintended consequence of misreporting of managers' information. The current research seeks to address these limitations and problems by positing a conceptual model for investigating budgetary slack within a "real practice" setting. The significance of such a model is described below. 


\section{Purpose and Significance}

Dual purposes guide the present research. The first purpose of this paper is to propose a model for the investigation of spending surges towards the end of a budgeting cycle. Identifying surges in departmental spending will help reduce unnecessary allocation of financial resources, as the total amount of spending prior to the surge could be a true indicator of budgetary need. This could also help an organization reallocate resources within the budget verses creating resources via alternative methods.

The second purpose of this paper is to explore the honesty of a department or budgetary unit by using slack levels as an indicator. Identifying which departments are spending unnecessarily will be important to the budgeting process. This identification will provide insight as to which department's self-interests are negatively impacting the organization.

Finally, work by Abdullah and Brink (2017) related to the ethical positioning in the creation of budgetary slack is based on an experimental model. While this does provide an extension of the research related to budgetary slack, as the authors note, "this study is subject to the limitations derived from the consequences of experimental research....it is limited by the generalizability of the results" (p. 21). To that end, the present proposed model is based on its ability to be applied in a practical departmental/organizational structure to test these effects on actual (not simulated) data.

\section{Research Questions}

The following research questions will guide the development of the conceptual framework proposed in the present research:

(1) To what extent can expiring budgets influence a surge in spending towards the end of a budgeting cycle?

(2) To what extent can slack indicate the honesty level of a department?

\section{Conceptual Framework}

The first model proposed attempts to identify spending surges toward the end of the budgetary cycle. The total spending for the year $(T)$ will be uniformly distributed over each week to get an average weekly spending (Avg. WS) for the year. To get the percentage of average weekly spending (Avg. WSP), the average weekly spending (Avg. WS) for the year would then be divided by the total spending for the year $(T)$. Next, actual spending for each week (Act. $W$ ) will be compared to total spending for the year $(T)$ to get the actual weekly percentage (Act. WSP). Formulas are presented below:

1) $A v g . W S=T / 52$

2) $A v g . W S P=A v g . W S / T$

3) Act. WSP = Act. W/ T

If actual weekly percentage (Act. WP) is significantly greater than average percentage of weekly spending (Avg. WP) for the year, then a spending surge may have been identified. 


\section{Macrothink}

International Journal of Accounting and Financial Reporting

ISSN 2162-3082

2018, Vol. 8, No. 2

The second model attempts to identify slack within the budget. In a study by Church et al. (2012), slack was calculated by subtracting actual cost from budgeted cost. The present research proposes use of a variation of this calculation by the taking the total spending for the year $(T)$ minus total spending prior to spending surge $(P S)$ to calculate slack $(S)$.

This formula is presented below:

4) $S=T-P S$

The closer the amount of slack $(S)$ is to zero, represents a lower level of slack present in the department's budget.

Once slack has been calculated, the third model can potentially be used to compute a department's level of honesty. The measure used to calculate honesty was adopted from Church et al. (2012) and Evans, Hannan, Krishnan, \& Moser (2001). Honesty (I) is computed by taking one minus slack $(S)$ divided by total spending prior to spending surge $(P S)$. Results from the calculation will range from zero to one. If departments behave honestly by spending actually what they need, the value is one. Values closer to zero reflect a dishonest department.

\section{Proposed Research Method}

The proposed model is based on a model of year-end spending as described by Liebman and Mahoney (2013).

At the beginning of each year, Congress chooses a budget for the agency. In each sub-year period, the agency draws a parameter that determines the marginal value of expenditures and chooses a level of spending to maximize an objective with decreasing returns (1).

The use of this model is appropriate because of (a) the cyclical nature of budgeting as well as (b) the use of shorter periods or benchmarks within the budgetary cycle. Additionally, the focus of spending in the context of maximizing objectives serves as a control element and allows for variability in budgeting based on initiatives within the organization.

In addition, the proposed model employs a measure of honesty as described by Church et al. (2012) and Evans et al. (2001). This measure takes a value from zero to one and represents the extent to which managers behave in an honest verses self-interested manner (Church et al., 2012).

\section{Data Collection Procedure}

Data should be obtained from each department within a medium to large organization. Small companies would ideally be eliminated because of the lack of an adequate comparison group (i.e., number of departments), thereby creating an insufficient basis from which to draw conclusions. Additionally, exceptionally small companies (those with less than 200 employees) may not have sufficient numbers of resources on which to base budgetary trends. Finally, small firms may lack a formal budgeting process, which could also lead to problems of generalizability of findings. 


\section{Mll Macrothink}

International Journal of Accounting and Financial Reporting

ISSN 2162-3082

2018, Vol. 8, No. 2

Potential data should include the budget provided to each department, as well as a list of each department's expenditures. Once financial information has been gathered from all appropriate departments, data analysis can begin.

\section{Data Analysis}

Data analysis related to the proposed model will involve grouping all expenditures by week (in which expenses are recognized). Missing dates for expenditures should be researched via procurement or related organizational structures, to minimize missing data. Dates will be important to examining expenditure trends towards the end of the budgeting cycle.

Many hypotheses could be tested using the model. Specific hypotheses to be tested might include:

(1) $\mathrm{H}_{1}$ : Expiring budgets lead to increased spending towards the end of a budgeting cycle. This would be tested with the year-end model presented by Liebman and Mahoney (2013).

(2) $\mathrm{H}_{2}$ : As slack levels within departments increase, their level of perceived honesty will decrease. Each department will be tested by using the honesty measure (Church et al., 2012).

Depending on additional contextual variables and circumstances, an abundance of potential additional hypotheses are possible.

\section{Contributions}

The proposed model provides a basis for several potential contributions to the budgetary slack literature. First, the model has the potential to expand on the understanding of spending trends a department has late in a budgeting cycle. This insight will assist budget and departmental managers to better allocate an organization's financial resources. Additionally, the proposed model has potential to identify spending trends of a department during the end of a budgeting period, and could also provide insight to slack levels within the department's budget. Finally, identifying levels of slack will help budgeters isolate problem departments within the larger organizational context.

\section{Limitations}

The model proposed here is subject to a number of possible limitations. Primarily, as with any type of conceptual model, related research is limited in terms of its generalizability. Application of the model could potentially yield outcomes that vary significantly based on both contextual and industry-specific factors. For example, within different industries, timing of expenditures can differ greatly. Therefore, the use and interpretation of this model could vary across different industries and business models. Ultimately, spending surges later in a budgetary cycle may not be the direct result of a department acting in unethical self-interest. Major purchases may be held until the end of a cycle to ensure financial resources are available as a necessary strategy for securing resources. 
Second, access to a company's budgetary information presents logistical problems. While publicly traded companies must report standard Securities \& Exchange Commission (SEC) filings, departmental level is not typically a formal part of such filings. Within most organizations, managerial accounting data is generally not available. Thus, accessing this type of information for the purpose of testing the model is problematic. The extent to which this data is centralized or decentralized could further complicate the access to, and collection of, such data.

\section{Suggestions for Further Research}

A theoretical model presents many opportunities for an expansion of the original idea through future research and scholarly efforts. The present model formulates a testable approach in an attempt to explain multiple facets of budgetary slack. Extensions of research questions and potential hypotheses presented in this paper that establish opportunities for future research. Specific opportunities are enumerated, below:

1 Research should be undertaken to test and validate the model in terms of its ability to predict the impact of expiring budgets on spending surges at different points during a budgeting cycle. While an emphasis would be placed on spending late in the cycle, studying variability of spending throughout would provide useful insights for organizational and departmental budgeting practitioners.

2 Additionally, potential research should investigate the relationship between budgetary slack and departmental honesty. Additional theoretical modeling may be necessary to identify factors related to measurement of honesty from a departmental level.

3 Post model validation studies should test specific hypotheses, such as those presented previously in this paper. For example, H1: Expiring budgets lead to increased spending towards the end of a budgeting cycle.

4 Additional post model studies should link perceptions of honesty (from various perspectives, including employees, competing budgets, management, etc.) in efforts to measure the impact of budgetary slack on perceived honesty. The multiple honesty measures could be incorporated, including that by Church et al., (2012).

\section{Conclusions}

Slack is a result of intentional reduced spending in early stages of a budgeting cycle. Unused resources may be used as a "rainy day" fund for potential future departmental expenditures. Surges in departmental spending could be identified as the end of a budgetary cycle draws near. Budgetary slack can negatively impact an organization's revenues and expenses, as well as the organization's ability to remain flexible and respond to changes. This can be attributed to the fact that additional resources used are at the benefit of individual departments and not necessarily those of the organization.

The conceptual model presented here can potentially help combat budgetary slack and associated negative impacts on organizations. By identifying departmental spending surges, companies should have a better understanding of each department's true budgetary needs. 


\section{Mll Macrothink}

International Journal of Accounting and Financial Reporting

ISSN 2162-3082

2018, Vol. 8, No. 2

This, in turn, could lead to reductions in allocations of unnecessary financial resources. This will enable an organization to better allocate resources to areas of strategic importance. In addition to the identification of unnecessary departmental spending, the proposed model potentially provides an assessment of honesty levels for specific departments. This could provide insights into how department's self-interests align with organizational objectives, as well as other related information.

\section{References}

Abdullah, I., \& Brink, A. G. (2017). The influence of horizontal equity, self-efficacy, and ethical position on the creation of budgetary slack. Journal of Theoretical Accounting Research, 12(2), 3-27.

Baiman, S., \& Lewis, B. L. (1989). An experiment testing the behavioral equivalence of strategically equivalent employment contracts. Journal of Accounting Research, 27(1), 1-20.

Church, B. K., Hannan, R. L., \& Kuang, X. J. (2012). Shared interest and honesty in budget reporting. Accounting, Organizations and Society, 37(3), 155-167.

Dunk, A. S. (1993). The effect of budget emphasis and information asymmetry on the relation between budgetary participation and slack. The Accounting Review, 68(2), 400-410.

Evans III, J. H., Hannan, R. L., Krishnan, R., \& Moser, D. V. (2001). Honesty in managerial reporting. The Accounting Review, 76(4), 537-559.

Gallani, S., Krishman, R., Marinich, E. J., \& Shields, M. D. (2018). Budgeting, psychological contracts, and budgetary misreporting. Harvard Business School Working Paper. Retrieved May 7, 2018 from http://www.hbs.edu/faculty/Publication\%20Files/16-017_2a81a4de-f2bf4d49-a9bc-bd69cbe34385.pdf

Goldstein, L. (2005). College and university budgeting: An introduction for faculty and academic administrators. Washington, DC: National Association of College and University Business Officers.

Hartmann, F. G., \& Maas, V. S. (2010). Why business unit controllers create budget slack: Involvement in management, social pressure, and Machiavellianism. Behavioral Research in Accounting, 22(2), 27-49.

Hobson, J. L., Mellon, M. J., \& Stevens, D. E. (2011). Determinants of moral judgments regarding budgetary slack: An experimental examination of pay scheme and personal values. Behavioral Research in Accounting, 23(1), 87-107.

Hurlburt, S., Kirshstein, R., \& Rossol-Allison, P. (2014) The ABCs of activity-based costing in community colleges. American Institutes for Research, 1-24. Retrieved from http://www.hartnell.edu/cost-and-efficiency

Jones, L. R. (2005). Outyear budgetary consequences of agency cost savings: International public management network symposium. International Public Management Review. Retrieved from http://calhoun.nps.edu/handle/10945/40250 


\section{Macrothink}

International Journal of Accounting and Financial Reporting ISSN 2162-3082 2018, Vol. 8, No. 2

Liebman, J. B., \& Mahoney, N. (2013). Do expiring budgets lead to wasteful year-end spending? Evidence from federal procurement. National Bureau of Economic Research, 1-68.

Liessem, T., Schedlinsky, I., Schwering, A., \& Sommer, F. (2015). Budgetary slack under budget-based incentive schemes - the behavioral impact of social preferences, organizational justice, and moral disengagement. Journal of Management Control, 26(1), 81-94.

Schiff, M., \& Lewin, A. Y. (1970). The impact of people on budgets. The Accounting Review, 45(2), 259-268.

\section{Copyright Disclaimer}

Copyright for this article is retained by the author(s), with first publication rights granted to the journal.

This is an open-access article distributed under the terms and conditions of the Creative Commons Attribution license (http://creativecommons.org/licenses/by/4.0/) 